\title{
The genus Mansoa (Bignoniaceae): a source of organosulfur compounds
}

\author{
Maria das Graças Bichara Zoghbi, ${ }^{, 1}$ Jorge Oliveira, ${ }^{1}$ Giselle Maria Skelding \\ Pinheiro Guilhon ${ }^{2}$ \\ ${ }^{1}$ Coordenação de Botânica, Museu Paraense Emílio Goeldi, PO Box 399, 66040-170 Belém-PA, Brazil \\ ${ }^{2}$ Faculdade de Química, Universidade Federal do Pará, Av. Augusto Corrêa 01, 66075-110 Belém-PA, Brazil
}

\begin{abstract}
RESUMO: “O gênero Mansoa (Bignoniaceae): uma fonte de compostos organosulfurados." $O$ gênero Mansoa pertence à família Bignoniaceae e inclui onze espécies que ocorrem principalmente nas florestas secas e úmidas do Brasil e da Argentina até o Sudeste do México. Essas espécies na Amazônia brasileira são conhecidas como "cipó-de-alho", em referência ao forte cheiro de alho das folhas quando esmagadas. O "cipó-de-alho" tem vários usos na medicina tradicional e entre eles, os mais citados são para tratamento de gripe, febre, dor e inflamação de artrite e reumatismo. Apesar de todos os usos, ainda tem pequena aplicação como fitoterápico quando comparado ao alho (Allium sativum). Os óleos essenciais de Mansoa spp. contêm polissulfetos de alila que contribuem para o aroma e sabor característicos. A composição química dos extratos orgânicos de Mansoa incluiu alcanos, alcanóis, triterpenóides, flavonóides, derivados do lapachol e o derivado sulfurado aliína. Os usos, composição química, atividades biológicas e aspectos agrícolas de espécies de Mansoa e sua relação com A. sativum são apresentados.
\end{abstract}

Unitermos: Mansoa, Bignoniaceae, composição química, atividades biológicas, aspectos agrícolas.

\begin{abstract}
The genus Mansoa belongs to the family Bignoniaceae and it includes eleven species that occur mainly in the dry and wet forests of Brazil and from Argentina to the Southeast of Mexico. These species in the Brazilian Amazon region are known as "cipó-de-alho", that means garlic vine, in reference to the pungent garlic-like smell of the leaves when crushed. "Cipó-dealho" has several uses in folk medicine and among them, the most cited are the treatment for cold, fever, pain and inflammation of arthritis and rheumatism. In spite of all those uses, it still has little application in phytotherapy when compared to garlic (Allium sativum). The essential oils of Mansoa spp. show the presence of allyl polysufides that contribute to the characteristic aroma and flavor. The chemical composition of the organic extracts of Mansoa has been reported and it includes alkanes, alkanols, triterpenoids, flavonoids, lapachol derivatives and organosulfur compound alliin. The uses, chemical composition, biological activities and agricultural aspects of Mansoa species and their relationship with $A$. sativum are presented.
\end{abstract}

Keywords: Mansoa, Bignoniaceae, chemical composition, biological activities, agricultural aspects.

\section{INTRODUCTION}

The genus Mansoa, as currently circumscribed, consists of eleven species: M. alliacea (Lam.) A. H. Gentry, M. angustidens (DC.) Bureau \& K. Schum., M. difficilis (Cham.) Bureau \& K. Schum., M. glaziovii Bureauu \& K. Schum., M. hirsuta DC., M. hymenaea (DC.) A. H. Gentry, M. lanceolata (DC.) A. H. Gentry, M. onohualcoides A. H. Gentry, M. parviflora (A. H. Gentry) A. H. Gentry, M. standleyi (Steyerm.) A. H. Gentry and $M$. verrucifera (Schltdl.) A. H. Gentry (Lhomann, 2009). Species of the genus Mansoa found in the Brazilian Amazon region are known as "cipó-de-alho", that means garlic vine, in reference the pungent garlic-like smell of the leaves when crushed. Its Spanish name is "ajo sacha", that means false garlic. Despite the similarities of the genera Mansoa and Allium and the folk-medicinal importance of Mansoa, the chemistry of this genus has not been extensively studied. The essential oils of onion (Allium cepa) and of garlic (A. sativum) have been subject of chemical investigation for over 100 years. According to Block and coworkers (1993), Werthein, in 1844, and Semmler, in 1892, carried out the first scientific investigations into the composition of the distilled garlic and onion oils. This paper attempts to summarize and to contribute to available knowledge of the uses, chemistry and biological properties of the genus 
Mansoa, primarily in the Amazon.

\section{Taxonomy and habitat}

According to Lawrence (1951), the genera of the family Bignoniaceae have achieved considerable notoriety for being difficult to recognize. Gentry (1973) explains this fact as being due mostly to two basic reasons: first, species have often been segregated on the basis of insignificant differences in part because the extent of variability of large trees or vines what is difficult to understand from herbarium specimens; the second basic reason involves the philosophy that has guided segregation of these genera. The last author also reports that especially the fruit characters must be reevaluated. The circumscription of Mansoa adopted by Lhomann (2009) excludes three species: $M$. erythraea (Dugand) A. H. Gentry, M. kerere (Aubl.) A. H. Gentry and $M$. ventricosa A. H. Gentry, that are distantly related to Mansoa and are treated as Pachyptera.

Mansoa occurs in dry and wet forests of Brazil and from Argentina to Southern Mexico (Lhomann, 2009). According to Revilla (2001), M. alliacea occurs on solid ground, not close to bodies of water, in shaded areas of low vegetation and in small primary forests. It cannot grow in flooded areas or in open fields. It occurs in tropical areas with rainfall of 1800-3500 mm/year, at temperatures between 20 and $30^{\circ} \mathrm{C}$. Mansoa hymenaea is a native plant of Brazil and Peru (Thetburanatham, 1987), but grows very well in most the parts of Thailand (Chirunthorn et al., 2005).

Mansoa alliacea (syn.: Bignonia alliacea Lam., Pseudocalymma alliacea (Lam.) Sandwith and Pachyptera alliacea (Lam.) A. H. Gentry) has already been the subject of previous studies on essential oils, non volatile compounds and biological activities, especially due to its commercial importance in other countries of the Amazon, mostly in Peru. This species has been cited as occurring in Brazil mostly in the State of Pará and being referred to by the common name of "cipó-de-alho". After extensive field observation (2006-2007) we found that M. standleyi (syn.: Pseudocalymma standleyi Steyerm., Pachyptera standleyi (Steyerm.) A. H. Gentry) has a large occurrence in the municipalities of the Northeast of Pará, where it is also known as "cipó-de-alho". Actualy, at this time, we could not find M. alliacea in this region, but only M. standleyi cultivated in gardens or occurring in the wild secondary forests. Mansoa standleyi was not registered in the region herbariums until our results. This is the first report of the occurrence of M. standleyi in the State of Pará.

\section{Common names}

Mansoa alliacea: Cipó-de-alho, cipó-d'alho, cipó-alho and alho-da-mata (Brazil), bejuco de ajo (Venezuela), garlic shrub (England), liana à l'all (France), ajo sacha (Peru), garlic creeper (India), garlic vine (USA).
Mansoa standleyi: cipó-de-alho (Brazil). Mansoa hirsuta: cipó-de-alho (Brazil).

\section{Traditional and local uses of Mansoa spp.}

Mansoa alliacea: The infusion of the dried aerial parts of M. alliacea has been used in Surinam as a vermifuge, to treat fever and rheumatic pains (Hasrat et al., 1997). The use of dried leaves in Peru includes the treatment of colds, pneumonia (Desmarchelier et al., 1997) and malaria, as an insecticidal (Pérez, 2002; Arana, 2005) and anti-rheumatic (Itokawa et al., 1992). In Brazil, infusions of the leaves of $M$. alliacea have been used to treat colds and fevers (Corrêa, 1931; Le Cointe, 1934; Silva et al., 1977; Pimentel, 1994), as a condiment (Pimentel, 1994), and as an analgesic for headache (Branch \& Silva, 1983). The tea made from the leaves is reported to be used in the treatment of cough, nausea and constipation (Berg, 1993). The oral or topical use of leaves, bark and roots in traditional medicine is reported as an analgesic, antipyretic and anti-rheumatic (Lorenzi \& Matos, 2002). The alcoholic maceration of the bark of the roots and the patch of the leaves were considered antirheumatic and anti-arthritic (Revilla, 2001). Infusion of the leaves has been used against fevers or colds and the aqueous maceration of the roots as a tonic (Revilla, 2001). In the Guianas the decoction of the stems and leaves has been used as an external wash against pains and muscular fatigue (Grenand et al., 1987). The indigenous people use the plant in magic or mystical rituals to scare away the bad spirits (Grenand et al., 1987). In Surinam, a piece of stem is kept in a glass of water and the water is drunk in the last month of pregnancy for a healthy confinement (DeFilipps et al., 2007). It is also used to repel bats and insects (burning leaves), in magical rituals to clean and to purify (leaves infusion) (Revilla, 2001). According to the same author, the fresh and dried leaves, bark, stem and roots of M. alliacea could be commercialized as a perfume fixative, as an ingredient used in perfumery or as a medicine to treat rheumatism and arthritic pains (alcoholic maceration of the bark and roots or by application of the patch of the leaves in the affected area); the infusion of the leaves could be used as an analgesic, in the treatment of arthritis (infusion of the leaves or application of the crushed leaves on the affected area), in the treatment of epilepsy (tea made of the bark) and headache (crushed leaves used as a patch on the forehead) or as a reviving tonic (aqueous maceration of the roots)

Mansoa hymenaea: It is used as an ornamental plant in Thailand because of its attractive large pink flowers (Chirunthorn et al., 2005). In South Africa it is used traditionally to treat rheumatoid arthritis and as a muscle relaxant (Luna, 1984).

Mansoa hirsuta: It is reported as an antifungal, 
antihypertensive, diuretic and an antitumor plant and it is used in the treatment of diabetes (Chaves \& Reinhard, 2003; Agra et al., 2007; 2008).

Mansoa standleyi: The decoction of the stems has been used for an external wash to treat fatigue and lameness or lumbago in the Guianas (Guyana, Surinam and French Guiana); the French Guiana Wayapi use macerated stems as an insecticide against ants (Atta sp.); the Tikuna of Colombia use the leaf for fevers and headache, while the Waorani of Ecuador use the stems and leaves for arthritis, fever and sore muscles (DeFilipps et al., 2007). It is also used in the state of Pará in the North of Brazil as an ornamental plant.

\section{Agricultural aspects}

The most used propagation process of “cipó-dealho" is by branch stakes, which should not be too green or too old when collected to be planted; the beds receive a mixture of earth with organic material to retain humidity and a cover that retains $40 \%$ of the light; the stakes should have 3 to 4 knots, of which 2 are beneath the earth and after they create roots, the seedlings are transferred to plastic bags; the seedlings should be ready to plant in the rainy season; the planting should be done in open holes and the fertilization can be done with organic material found in the same area of the planting and at a short distance from a tree; during the growth of the plant it should be directed toward a tree with a guide; the harvest of the leaves is done manually (Pimentel, 1994). The leaves should be dried in the shade for conservation, roots and stems can be dried in the sun daily and the leaves should be processed before three months and roots and stems before 6 months, keeping them always in a dry and open area (Revilla, 2001).

\section{Economic aspects}

The production of "cipó-de-alho" comes from domiciliary plantation for familiar use and small commercial plantations, but the largest production comes from the harvest directly from the forest, where it is very common. In Iquitos (Peru), there are commercial plantations in a small scale; it is commercialized as a medicinal plant at a retail price of US $0.28 / \mathrm{kg}$ making US $2,700.00$ to $4,200.00 /$ ha/year and at a wholesale price of US $0.14 / \mathrm{kg}$ making US 1,400.00 to 2,100.00/ha/year (Revilla, 2001). In Belém, State of Pará (Brazil), it is commercialized in open-markets for US 1.00 each bunch $(\sim 170 \mathrm{~g})$.

\section{Biological activities}

Mansoa alliacea. Dried flowers of $M$. alliacea when fed at a $2 \%$ level in a diet for six weeks to experimental rats rendered hypercholesterolemia by cholesterol feeding, exhibiting blood cholesterol lowering effect, by lowering the absorption of dietary cholesterol from intestine, like other sulfur containing spices (Srinivasan \& Srinivasan, 1995). Aqueous extract of the leaves showed a broad fungi toxic spectrum by inhibiting the spore germination of Alterniaria brassicae (Berk.) Sacc. in $72 \%$ after 5 min of exposure and in 100\% after $10 \mathrm{~min}$; it was also observed that, nevertheless the inhibitory principle of the extract had a good shelf life at $10^{\circ} \mathrm{C}$ and was thermo stable when kept for $1 \mathrm{~h}$ at $60^{\circ} \mathrm{C}$ and on boiling at $100{ }^{\circ} \mathrm{C}$ for $3 \mathrm{~min}$, the inhibitory activity of the extract decreased to $70 \%$ on boiling for $5 \mathrm{~min}$ and was completely lost after boiling for 10 min (Bhupendra et al., 1999). Leaves of M. alliacea exhibited antifungal activity completely inhibiting the mycelia growth of the fungi Drechslera oryzae; the author concluded that the activity was due the essential oil at its minimal inhibitory concentration was of $500 \mathrm{ppm}$ (Chaturvedi et al., 1987). Moderate antimicrobial activity of the leaf essential oil of $M$. alliacea was demonstrated by Ganapaty \& Beknal (2004). The aqueous extract of the leaves of $M$. alliacea from India showed activity against several fungi: Colletotrichum capsici, Curvularia lunata, Alternaria alternata, A. brassicae, A. brassicola, A. carthami, Fusarium oxysporum and F. udum (Rana et al., 1999). Antiviral activity against plant pathogens (virus-mild mosaic) was reported by Khurana \& Bhargava (1970) for the ethanol extract of the leaves. Aqueous extract of dried leaves of $M$. alliacea from India showed antimicrobial activity (Rao \& Rao, 1985). The leaf aqueous extract of the plant from Peru showed antioxidant activity (Desmachelier et al., 1997); weak anti-inflammatory activity was observed in ethanol extract of dried root and stem of a specimen collected in Peru (Dunstan et al., 1997). Prostaglandin synthesis inhibition was reported for the ethanol extract (Dunstan et al., 1997). The influence of $M$. alliacea in the ethological control of Hipsiphyla grandella Zeller on young plants of Cedrela odorata L. was evaluated and the authors observed the control of $74 \%$ of the attack by $H$. grandella (Arana, 2005). The biocide action of the leaves of $M$. alliacea, when burned, against Anofeles was reported by Pérez (2002).

Mansoa hirsuta: The ethanol extract of M. hirsuta DC. inhibited the growth of standardized cultures of Aspergillus niger and Fusarium oxysporum, at concentrations of $400 \mu \mathrm{g}$ and $500 \mu \mathrm{g}$ in bioautographic assays (Rocha et al., 2004); the authors conclude that alkanols and alkanodiols present in the ethanol extract may be regarded as the antifungal constituents of $M$. hirsuta. High antihypertensive activity was showed by the leaves of M. hirsuta (54\%) (Braga et al., 2000).

Mansoa hymenaea: The petroleum ether extract of leaves of $M$. hymenaea (DC.) A. Gentry showed higher activity in the brine shrimp toxicity test $\left(\mathrm{IC}_{50}\right.$ of $\left.268 \mu \mathrm{g} / \mathrm{mL}\right)$ when compared to the ethanol extract ( $\mathrm{IC}_{50}$ of $428 \mu \mathrm{g} / \mathrm{mL}$ ); the antioxidant activity of petroleum extract was three times 
higher than of that of the ethanol extract $\left(\mathrm{EC}_{50}=9.0\right.$ and $65.7 \mu \mathrm{g} / \mathrm{mL}$, respectively) and it was comparable to that of BHT $(16 \mu \mathrm{g} / \mathrm{mL})$; the pediculicidal and antimicrobial activities were higher in the petroleum ether extract than in the ethanol extract; the ethanol extract showed high cytotoxic activity against lung cancer cell line, but both extracts showed negative results against all gram negative bacteria and some positive bacteria (Streptococcus faecalis), but showed high antifungal activity, especially against three fungal species (Trichophyton rubrum, T. mentagrophytes and Microsporum gypseum) with MIC less than $20 \mu \mathrm{g} / \mathrm{mL}$ (Chirunthorn et al., 2005). The methanolic extract of the wood of $M$. hymenaea had cytotoxic activity against V-79 cells (colon cancer cell line) (Itokawa et al., 1992). The dichloromethane and methanolic extracts of the leaves showed antifungal activity against Trichophyton mentagrophytes and Microsporum gypseum (Freixa et al., 1998). The petroleum ether extract of the leaves showed high antifungal activity against dermatophyte fungi and the ethanolic extract showed high cytotoxic activity against lung cancer (Chirunthorn et al., 2005).

\section{Chemical composition}

\section{Non volatiles compounds}

Mansoa alliacea: The methanol extract of the flowers of Mansoa alliacea collected in India yielded $\beta$-amyrin (1) and $\beta$-sitosterol (2), ursolic acid (3), $\beta$-sitosteryld-glucoside (4), the flavones apigenin (5), luteolin (6) and 7-O-methylscutellarein (7), the flavone glucoside apigenin-7-glucoside (8) and the flavones glucuronides apigenin-7-glucuronide (9), scutellarein-7-glucuronide (10), apigenin-7-glucuronyl glucuronide (11) and apigenin-7-O-methylglucuronide (12) (Rao \& Rao, 1980). The structure of compound 12 was latter confirmed (Rao \& Rao, 1982a). Alliin (13) was found in the flowers of $M$. alliace $a$ in a percentage of $1.76 \%$ (calculated on dry basis) and was compared to that found on garlic (2.34\%) (Rao \& Rao, 1982b). Floral pigments of M. alliacea collected in the United States afforded cyanidin-3- rutinoside (14) (Scogin, 1980). The dichloromethane phase of the methanol extract of the wood of $M$. alliacea collected in Iquitos (Peru) gave 9-methoxy- $\alpha$-lapachone (15) and 4-hydroxy-9-methoxy- $\alpha$-lapachone (16) (Itokawa et al., 1992). The cold aqueous extract of the leaves of $M$. alliacea collected in India showed the presence of common plant amino acids, while the analysis of the hot $70 \%$ methanol extract revealed the presence of a dominant amino acid, alliin (13), together amino acids with the same pattern prevailing in the cold extract (Rao et al., 1981). The percentage of alliin found in the leaves calculated on a dry basis was $2.15 \%$ (Rao \& Rao, 1982b). The petrol extract of the dried and powered leaves of $M$. alliacea collected in the gardens of Gorakhpur (India) afforded the aliphatic compounds 32-hydroxyhexatriacontan- 4-one (17) and 19-hydroxyhexatriacontan-18-one (18) (Misra et al., 1989), pentatriacont-1-en-17-ol (19) and 34-hydroxy-8-methylheptatriacontan-5-one (20) (Misra et al., 1991), $n$-alkanes $\mathrm{C}_{25}-\mathrm{C}_{35}(\mathbf{2 1}), n$-alkanols (22) and the steroids stigmasterol (23), $\beta$-sitosterol (2), fucosterol (24), 24-ethylcholest-7-ene-3 $\beta$-ol (25) (Sharma, 1993). The triterpenoids glycyrrhetol (26) and $\beta$-peltoboykinolic acid (27) (Pandey et al., 1992) and 3 $\beta$-hydroxyurs-18-en27-oic acid (28) were also obtained from the leaves (Misra et al., 1995).

Mansoa hirsuta: Fractionation of the ethanol extract of the leaves of $M$. hirsuta collected in Brazil lead to the identification of the following alkanols, alkanediols and ketones: 2,5-dimethyhexane-3,4-diol (29), 1-ethoxy4-methylpentan-2-one (30), 7-methyloctan-4-ol (31), 4-methylhexan-3-ol (32), hexan-3-ol (33), 5-methylhexan2-one (34), 4-methylpentan-2-ol (35), hex-5-en-2-ol (36), hex-2-en-1-ol (37), 2,3,3-trimetylpent-1-ene (38), hex-1in-3-ol (39) (Rocha et al., 2004).

Mansoa hymenaea: Lapachone (40) was isolated from the wood of M. hymenaea (Chirunthorn et al., 2005).

\section{Essential oils}

Mansoa alliacea: Volatiles of the fresh flowers and leaves of $M$. alliacea from India were identified by GLC in the ethereal extract obtained after steam distillation (Rao et al., 1978). The essential oil was characterized by the presence of diallyl disulfide (41), diallyl trisulfide (42) and diallyl tetrasufide (43), a mixture formely encountered within the Allium genus. Besides the diallyl sulfides, 1-octen-3-ol (44) also was identified. The essential oil from the air-dried leaves of a specimen collected in the municipality of Belém (State of Pará, in the North of Brazil), was rich in diallyl sulfides; in this sample, the proportion of diallyl disulfide (41) $(31.38 \%)$ and diallyl trisulfide (42) (30.55\%) was 1:1, the same one observed in the sample from India (Zoghbi et al., 1984). Other sulfur compounds were identified in this work: diallyl monosulfide (45, traces), allyl methyl disulfide (46), dithiacyclopentene (47), allyl propyl disulfide (48), allyl methyl trisulfide (49), 3-vinyl-1,2-dithi-5-ene (50), trithiacyclohexene (51), 3-vinyl-1,2-dithi-4-ene (52), allyl propyl trisulfide (53), allyl methyl tetrasulfide (54) and diallyl tetrasulfide (43). The oil from fresh leaves of a specimen of $M$. alliacea collected in Ananindeua (State of Pará, Brazil) afforded other compounds: 2-methyl2-pentenal (55), cis-dipropenyl disulfide (56), transdipropenyl disulfide (57), methyl salicylate (58) and propenyl propyl trisulfide (59); the compounds 1-octen-3ol (44), allyl isobutyl sulfide (60), diallyl disulfide (41), allyl methyl trisulfide (49), 3-vinyl-1,2-dithi-5-ene (50), methyl salicylate (58), 3-vinyl-1,2-dithi-4-ene (52), 3,4dimethyl-2,3-dihydrothiophen-2-one (61), allyl isobutyl disulfide (62), diallyl trisulfide (41), nonanethiol (63), 
<smiles>CC1(C)CC[C@]2(C)CC[C@]3(C)C(=CCC4[C@@]5(C)CC[C@@H](O)C(C)(C)[C@H]5CC[C@]43C)C2C1</smiles>

1<smiles>C[C@H]1CC[C@]2(C(=O)O)CC[C@]3(C)C(=CCC4[C@@]5(C)CC[C@H](O)C(C)(C)C5CC[C@]43C)C12</smiles>

3<smiles>[R]c1cc(-c2cc(=O)c3c(O)c([R])c([R])cc3o2)ccc1O</smiles>

$5 \mathrm{R}_{1}=\mathrm{H}, \mathrm{R}_{2}=\mathrm{OH}, \mathrm{R}_{3}=\mathrm{H}$

$6 \mathrm{R}_{1}=\mathrm{OH}, \mathrm{R}_{2}=\mathrm{OH}, \mathrm{R}_{3}=\mathrm{H}$

$7 \mathrm{R}_{1}=\mathrm{H}, \mathrm{R}_{2}=\mathrm{OMe}, \mathrm{R}_{3}=\mathrm{OH}$

$8 \mathrm{R}_{1}=\mathrm{H}, \mathrm{R}_{2}=O$-glucopyranosyl, $\mathrm{R}_{3}=\mathrm{H}$<smiles>[R6]O[C@H]1CC[C@@]2(C)C(=CCC3C4CC[C@H](C(C)CC[C@H](CC)C(C)C)[C@]4(C)CC[C@H]32)C1</smiles>

$2 \mathrm{R}=\mathrm{H}$

$4 \mathrm{R}=\beta$-D-glucopyranosyl<smiles>C=CC[Si](=C)([O-])CC(N)C(=O)O</smiles>

13<smiles>[R20]c1c(OC2OC(CO)C(O)C(O)C(O)C2O)cc2oc(-c3ccc(O)cc3)cc(=O)c2c1O</smiles>

$9 \mathrm{R}_{1}=\mathrm{H}, \mathrm{R}_{2}=\mathrm{H}$

$10 \mathrm{R}_{1}=\mathrm{OH}, \mathrm{R}_{2}=\mathrm{H}$

$11 \mathrm{R}_{1}=\mathrm{H}, \mathrm{R}_{2}=\mathrm{H}$ extra glucuronsyl unit

$12 \mathrm{R}_{1}=\mathrm{H}, \mathrm{R}_{2}=\mathrm{Me}$ (uncertain link) diisoamyl disulfide (64), diallyl tetrasulfide (43) and allyl propyl tetrasulfide (65) were identified from the pentane extract of the fresh flowers (Zoghbi et al., 2002). Sulfur compounds were identified as major compounds in the oil from fresh leaves of $M$. alliacea collected in India: diallyl tri, tetra and monosulfides (41-43 and 45) and ethyl allyl sulfide (66) (Ganapaty \& Beknal, 2004). Analyses of the oil from M. alliacea leaves led to the identification of diallyl trisulfide (42) (44.0\%) and diallyl disulfide (41) (37.0\%) as major constituents, together with 1-octen-3-ol (44) $(5.0 \%)$ and diallyl tetrasulfide (43) (4.0\%) (Rao et al., 1999).

\section{Aspects of Mansoa and Allium sativum chemistry and associated bioactivity}

Since ancient times, garlic (A. sativum) has been used worldwide not only as food but also as medicine (Freeman \& Kodera, 1995). Historically, garlic and other Allium species have been utilized in folk medicine for the treatment of burns, wounds, headaches, chest colds and rheumatism (Block, 1994). According to Brodnitz and coworkers (1971), the early studies of Semmler in 1892 establish the importance of diallyl disulfide (41) and the diallyl trisulfide (43) in the flavor of garlic distillates and the investigations of Cavallito in 1944 and 1945 and of Stoll and Seebeck in 1948 showed that the colorless solid, quite heat stable and odorless alliin (13) is a natural constituent of fresh garlic and when garlic is crushed or chopped it is converted by the enzyme alliinase to the odoriferous liquid allicin, $\mathrm{CH}_{2}=\mathrm{CHCH}_{2} \mathrm{~S}(\mathrm{O}) \mathrm{SCH}_{2} \mathrm{CH}=\mathrm{CH}_{2} \quad$ (67), which is further converted to the polysulfides. Alliin (13) and several polysulfides were identified from M. alliacea, as cited.

Some of the sulfur compounds identified from the genus Mansoa and Allium are known to have important biological activities. When the effect of alliin (13) is observed in blood cells in vitro, a noted increase in the engulfing capacity of phagocyting cell is seen (Salman et al., 1999). This compound, as well as the A. sativum powder, was shown to be a very good hydroxyl radical scavenger (Kourounakis \& Rekka, 1991). Allicin (67) is known to possess antimicrobial properties affecting the RNA synthesis of microorganisms, it also affects the biosynthesis of lipids in mammals, yeast and superior plants with inhibition of acetyl-CoA of the last ones 
<smiles>C=CC[Si](C)([O-])CCC(N)C(=O)O</smiles>

13<smiles>CCCCCCC(O)CCC(=O)CCC</smiles>

17

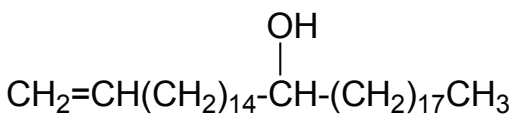

19

$$
\begin{gathered}
\mathrm{CH}_{3}\left(\mathrm{CH}_{2}\right) \mathrm{nCH}_{3} \\
21 \mathrm{n}=23-33 \\
\mathrm{CH}_{3}\left(\mathrm{CH}_{2}\right) \mathrm{nCH}_{2} \mathrm{OH}
\end{gathered}
$$

$22 n=24-32$

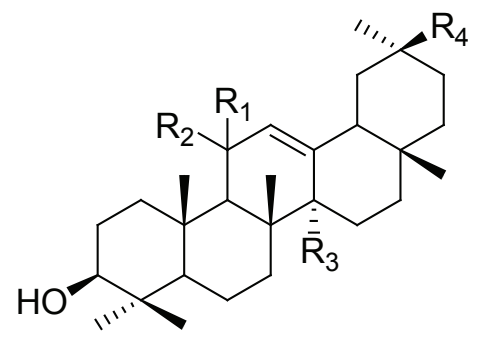

$26 \mathrm{R}_{1}, \mathrm{R}_{2}=\mathrm{O}, \mathrm{R}_{3}=\mathrm{CH}_{3}, \mathrm{R}_{4}=\mathrm{CH}_{2} \mathrm{OH}$ $27 \mathrm{R}_{1}=\mathrm{R}_{2} \mathrm{H}, \mathrm{R}_{3} \mathrm{CO}_{2} \mathrm{H}, \mathrm{R}_{4}=\mathrm{CH}_{3}$<smiles>[R]C1CC(C)(C)OC2C(=O)c3c(OC)cccc3C(=O)C12</smiles>

$15 \mathrm{R}=\mathrm{H}$

$16 \mathrm{R}=\mathrm{OH}$

$\mathrm{CH}_{3}\left(\mathrm{CH}_{2}\right)_{16} \stackrel{\mathrm{II}}{\mathrm{O}-\mathrm{O}}-\mathrm{H}$

18
20<smiles>[R20]C1CC[C@]2(C)C(=CCC3C4CC[C@H](C(C)CC[C@H](CC)C(C)C)[C@@]4(C)CC[C@@H]32)C1</smiles>

$23 \mathrm{R}=\mathrm{H}, \Delta^{22}$

$24 \mathrm{R}=\mathrm{H}, \Delta^{24(28)}$

$25 \mathrm{R}=\mathrm{H}, 5,6$-dihydro, $\Delta^{7}$<smiles>CC1=C2C3CCC4C(C)(C)[C@H](O)CC[C@@]4(C)[C@@]3(C)CC[C@]2(C(=O)O)CCC1(C)C</smiles>

28 
<smiles>CC(C)C(O)C(O)C(C)C</smiles>

29<smiles>CCCC(O)CC</smiles>

33<smiles>CCC/C=C/CO</smiles>
37<smiles>CCOCC(=O)CC(C)C</smiles>

30<smiles>CC(=O)CCC(C)C</smiles>

34<smiles>C=C(C)C(C)(C)CC</smiles>

38<smiles>CCCC(O)CCC(C)C</smiles>

31<smiles>CC(C)CC(C)O</smiles>

35<smiles>C#CC(O)CC</smiles>

39<smiles>CCC(C)C(O)CC</smiles>

32<smiles>C=CCCC(C)O</smiles>

36<smiles>CC(C)=CCC1C(=O)c2ccccc2C(=O)C1O</smiles>

40<smiles>C=CC[SiH2]CC=C</smiles>

$41 \mathrm{n}=2$

$42 \mathrm{n}=3$

$43 \mathrm{n}=4$

$44 n=5$

$45 \mathrm{n}=1$<smiles>C1=CSSC1</smiles>

47<smiles>C1=CSSSC1</smiles>

51<smiles>C=CC[SiH2]C</smiles>

$46 \mathrm{n}=2$

$48 \mathrm{n}=3$

$54 \mathrm{n}=4$<smiles>C=CC1CCCSS1</smiles>

$50 \Delta^{5}$

$52 \Delta^{4}$<smiles>C=CC[SiH2]CC(C)C</smiles>

$60 \mathrm{n}=1$

$61 n=2$

$$
\mathrm{CH}\left(\mathrm{CH}_{2}\right)_{7} \mathrm{CH}_{2} \mathrm{SH}
$$<smiles>CC1=CSC(=O)C1C</smiles>

61
63<smiles>C=CC(O)CCCCC</smiles>

44

$$
\begin{aligned}
& 49 n=2 \\
& 53 n=3 \\
& 65 n=4
\end{aligned}
$$$$
\gamma^{[\mathrm{S}] \mathrm{W}}
$$<smiles>C/C=C\[SiH]/C=C\C</smiles>

$[\mathrm{S}]_{2}$

57<smiles>C=CC[AsH2]CCC</smiles>

59<smiles>CC(C)CC[AsH2]CCC(C)C</smiles>

64<smiles>CCC=C(C)C=O</smiles>

55<smiles>C=CCSCC</smiles>

66<smiles>CC(=O)c1ccccc1O</smiles>

56 
(Block et al., 1993). Diallyl disulfide (41) has anticancer activities (Ariga \& Seki, 2006). It showed inhibitory effect on the proliferation of human tumor cells, it suppresses the growth of human colon tumor cell xenografts in athymic nude mice and inhibits the proliferation of human colon tumor cells in culture (Sundaram \& Milner, 1996a,b) and induced apoptosis through activation of caspase- 3 in human leukemia HL-60 cells (Kwon et al., 2002). Diallyl trisulfide (42) induced apoptosis in human prostate cancer cells (Xiao \& Singh, 2006). Some of the allyl sulfur compounds that have been found to alter significantly the proliferation of neoplasic cells include compounds allicin (67) (effective in lymphoid cells), diallyl sulfide (45) (prostate, leukocytes), diallyl disulfide (41) (lung, colonic, skin, prostate, mammary), diallyl trisulfide (42) (lung) (Milner, 2001). The number of sulfur atoms has been demonstrated by several authors as one main factor in the degree of efficiency protection, with diallyl trisulfide $>$ diallyl disulfide $>$ diallyl sulfide (Sakamoto et al., 1997, Sundaram \& Milner, 1995, Tsai et al., 1996). The ability of allyl sulfides to inhibit the growth of transplanted solid tumors in mice has been described after diallyl disulfide (41) and allicin (67) administration (Singh et al., 1996) Diallyl trisulfide (42) significantly reduced the liver injury caused by $\mathrm{CCl}_{4}$ (Fukao et al., 2004). Manivasagam and coworkers (2005) demonstrated that diallyl disulfide (41) could possess chemopreventive effects by modulating the oxidant-antioxidant status of the living system. Wagner and coworkers (1987) showed the effects of garlic constituents on the arachidonate metabolism. Diallyl disulfide (41) strongly inhibited the PG-synthetase and 5-lipoxygenase and probably the allylic structure is required for any activity, while dithiin compounds (50 and 52) only showed little influence on 5-lipoxygenase. The cholesterol-lowering effect of garlic extracts and organosulfur compounds has been shown (Yeh \& Liu, 2001). Lau and coworkers (2001) demonstrated that the durability of the inhibitory effect for human LDL oxidation was increased by garlic extract and by some of its compounds, including alliin (13) and allicin (67). It was elucidated that the alk(en)yl substituents and the number of the sulfur atoms were important for the antioxidative activity and among the sulfur-containing compounds, the higher antioxidant activity for human LDL was showed by 3-vinyl-1,2-dithi-5-ene (50) (Higuchi et al., 2003). Diallyl disulfide (41) and diallyl trisulfide (42) have been found to possess larvicidal activity to Culex pipiens (Block, 1981; Amonkar \& Banerji, 1971). The commercialization of a biochemical pesticide called Alli-UpTM containing 90\% of diallyl sulfides with $8.90 \%$ of monosulfide (45), 86.90\% of disulfide (41), 3.90\% of trisulfide (42) and $0.30 \%$ of tetrasulfide (43), that is used to control white rot (Sclerotium cepivorum) in onions, garlic and leeks (U.S. Protection Environment Agency, 2003) reinforces the insecticidal activity of these sulfides.

Non-sulfur compounds from Mansoa species also showed biological proprieties. The antitumor (in vitro against V-79 tumor cells) activity of $M$. alliacea was attributed of the naphthoquinones 9-methoxy- $\alpha$-lapachone (15) and 4-hydroxy-9-methoxy- $\alpha$-lapachone (16) (Itokawa et al., 1992). Aliphatic compounds (29-39) may be regarded as the antifungal components of $M$. hirsuta (Rocha et al., 2004). Antibacterial properties of $M$. alliacea were attributed to $n$-alkanes $\mathrm{C}_{29}, \mathrm{C}_{31}$ and $\mathrm{C}_{33}$ (Sharma, 1993).

\section{CONCLUSIONS}

The close chemical relationship between $M$. alliacea and $A$. sativum has been reported by some authors that showed that the essential oils of the two species were characterized by high amount of allyl sulfides and among them, allyl disulfide and allyl trisulfide were major (Figure 6). It is noteworthy the fact that the chemical composition of these oils are similar, but very little of $M$. alliacea is commercialized when compared to garlic. Both, garlic and "cipó-de-alho" are used as spices. In some regions in the North of Brazil, the fresh leaves of "cipó-de-alho" replace garlic as a condiment. Health benefits have been attributed to "cipó-de-alho" that is a common medicinal plant in the Amazon. The most cited uses include treating the pain and inflammation of arthritis and rheumatism, as well as, colds, flu, fever etc. Theses traditional uses are somewhat close to those cited to garlic. Many important biological activities are attributted to the sulfur and nonsulfur compounds found in Mansoa and in garlic. The compounds found in Mansoa alliacea and in some Allium species have biological proprieties that explain, at least in part, of the uses of "cipó-de-alho" in folk medicine. $M$. alliace $a$ is commercialized as a medicinal plant, especially in Peru and in a smaller scale in the North of Brazil and it is the most studied species of the genus. There are very little chemical and biological studies on other Mansoa species. Other species of Mansoa have a garlic-like flavor and can be considered, together with $M$. alliacea, possible sources of diallyl sulfides. Mansoa standleyi was found to occur very frequently in the Northeast of the State of Pará in the North of Brazil. According our knowledge this is the first report on the occurrence of $M$. standleyi in the North of Brazil.

\section{ACKNOWLEDGEMENTS}

The authors are grateful to PPG-7/CNPq/MCT by financial support.

\section{REFERENCES}

Agra MF, França PF, Barbosa-Filho JM 2007. Synopsis of the plants known as medicinal and poisonous in Northeast of Brazil. Rev Bras Farmacogn 17: 114-140.

Agra MF, Silva KN, Basílio IJLD, França PF, Barbosa-Filho JM 2008. Survey of medicinal plants used in the region Northeast of Brazil. Rev Bras Farmacogn 18: 472-508.

Amonkar SV, Banerji A 1971. Isolation and characterization of of 
larvicidal principle of garlic. Science 174: 1343-1344.

Arana VF 2005. Control de Hipsiphyla grandella Zeller en plantaciones de Cedrela odorata L. (cedro rojo) con Mansoa alliacea (Lam.) A. H. Gentry (ajo sacha). Conocimiento 8: 59-67.

Ariga T, Seki T 2006. Antithrombotic and anticancer effects of garlic-derived sulfur compounds: a review. BioFactors 26: 93-103.

Berg ME van den 1993. Plantas medicinais da Amazônia: contribuição ao seu conhecimento sistemático. $2^{\text {nd }}$ ed. rev. Belém: Museu Paraense Emílio Goeldi, Coleção Adolpho Ducke.

Bhupendra KR, Taneja V, Singh UP 1999. Antifungal activity of an aqueous extract of leaves of garlic creeper (Adenocalymma alliaceum Miers.). Pharm Biol 37: 1316.

Block E 1981. Low-molecular-weight organosulfur compounds in nature: the search for new pesticides. In Rosen JD, Magee PS, Casida JE (Eds.), Sulfur in Pesticide Action and Metabolism. Washington DC: ACS Symposium Series 158, ACS, p. 3-16.

Block E 1994. Flavolants from garlic, onion and other Allium and their cancer-preventive proprieties. In Huang MT, Osawa T, Ho CT, Rosen RT (Eds.), Food Phytochemicals for Cancer Prevention. Washington DC: ACS Symposium Series 546, ACS, p. 84-96.

Block E, Naganathan S, Putman D, Zhao S-H 1993. Organosulfur chemistry of garlic and onion: recent results. Pure Appl Chem 65: 625-632.

Braga FC, Wagner H, Lombardi JA, Oliveira AB 2000. Screening the Brazilian flora for antihypertensive plant species for in vitro angiotensin-1-converting enzyme inhibiting activity. Phytomedicine 7: 245-240.

Branch LC, Silva MF 1983. Folk medicine of Alter do Chão, Pará, Brasil. Acta Amazonica 13: 737-797.

Brodnitz MH, Pascale JV, Slice L van der 1971. Flavor components of garlic extract. J Agric Food Chem 19: 273-275.

Chaturvedi R, Dikshit A, Dixit SN 1987. Adenocalymma alliacea, a new source of a natural fungitoxicant. Trop Agr 64: 318-322.

Chaves SAM, Reinhard KJ 2003. Paleopharmacology and pollen: theory, method and application. Mem I Oswaldo Cruz 98 (Suppl 1): 207-211.

Chirunthorn R, Supavita T, Intaraksa N, Kummee S, Junkong N, Chisorn B, Itharat A 2005. Study on biological activities of Mansoa hymenaea (DC.) A. Gentry leaf extracts. $J$ Sci Technol 27 (Suppl. 2): 489-495.

Corrêa MP 1931. Dicionário das Plantas Úteis e das Exóticas Cultivadas. Rio de Janeiro: Imprensa Nacional.

DeFilipps RA, Maina SL, Crepin J 2007. Medicinal plants of the Guianas (Guyana, Surinam, French Guiana). http://www. mnh.si.edu/biodiversity/bdg/medicinal/MedPlantsGuil. pdf. p. 52, accessed on Feb 23, 2008.

Desmachelier C, Repetto M, Coussio J, Llesuy S, Ciccia G 1997. Total reactive antioxidant potential (TRAP) and total antioxidant reactivity (TAR) of medicinal plants used in Southwest Amazonia (Bolivia and Peru). Int $J$ Pharmacog 35: 1-9.

Dunstan CA, Noreen Y, Serrano G, Cox PA, Perera P, Bohlin L 1997. Evaluation of some Samoan and Peruvian medicinal plants by prostaglandin biosynthesis and rat ear oedema assays. J Ethnopharmacol 57: 35-56.

Freeman F, Kodera Y 1995. Garlic chemistry: stability of S-(2- propenyl) 2-propene-1-sulfinothioate (allicin) in blood, solvents and simulated physiological fluids. J Agric Food Chem 43: 2332-2338.

Freixa B, Vila R, Vargas L, Lozano N, Adzet T, Canigueral S 1998. Screening for antifungal activity of nineteen Latin American plants. Phytother Res 12: 427-430.

Fukao T, Hosono T, Misawa S, Seki T, Ariga T 2004. Chemoprotective effect of diallyl trisulfide from garlic against carbon tetrachloride induced acute liver injury of rats. Biofactors 21: 1-4.

Ganapaty S, Beknal AK 2004. Composition of leaf oil from Adenocalymma alliaceum and its antimicrobial activity. Indian Perfumer 48: 323-326.

Gentry AH 1973. Generic delimitations of Central American Bignoniaceae. Brittonia 25: 226-242.

Grenand P, Moretti C, Jacquemin H 1987. Pharmacopées traditionnelles en Guyane: Créoles, Palikur, Wayãpi (Collection Mémoires no 108), Paris, ORSTOM, 569 p.

Hasrat JA, De Backer JP, Vanquelin G, Vlietinck AJ 1997. Medicinal plants in Suriname: screening of plant extracts for receptor binding activity. Phytomedicine 4: 59-65.

Higushi O, Tateshita K, Nishimura H 2003. Antioxidative activity of sulfur-containing compounds in Allium species for human low-density lipoprotein (LDL) oxidation in vitro. J Agric Food Chem 51: 7208-7214.

Itokawa H, Matsumoto K, Morita H, Takeya K 1992. Cytotoxic naphtoquinones from Mansoa alliacea. Phytochemistry 31: 1061-1062.

Kourounakis PN, Rekka E 1991. Effect on active oxygen species of aliin and Allium sativum (garlic) powder. Res Commun Chem Pathol Pharmacol 74: 249-252.

Khurana SMP, Bhargava KS 1970. Effect of plant extracts on the activity of three papaya viruses. J Gen Appl Microbiol 16: 225-230.

Kwon KB, Yoo SJ, Ryu DG, Yang JY, Rho HW, Kim JS, Park JW, Kim HR, Park BH 2002. Induction of apoptosis by diallyl disulfide through activation of caspase-3 in human leukemia HL-60 cells. Biochem Pharmacol 63: 41-47.

Lau BH 2001. Suppression of LDL oxidation by garlic. J Nutr 131: $985 \mathrm{~S}-988 \mathrm{~S}$.

Lawrence HM 1951. Taxonomia das plantas vasculares, vol. 2. Lisbon: Fundação Calouste Gulbenkian.

Le Cointe, P 1934. A Amazônia brasileira III: árvores e plantas úteis (indígenas e aclimatadas). Belém: Livraria Clássica.

Lohmann LG 2007. A new generic classification of Bignonieae (Bignoniaceae) based on molecular phylogenetic data and morphological synapomorphies. Ann Missouri Bot Gard. In Press.

Lorenzi H, Matos F JA2002. Plantas Medicinais no Brasil, nativas e exóticas. Nova Odessa (SP): Instituto Plantarum.

Luna LE 1984. The healing practices practices of a Peruvian shaman. J Ethnopharmacol 11: 123-133.

Manivasagam T, Subramanian P, Suthakar G, Essa MM 2005. The chemopreventive effect of diallyl disulphide on $\mathrm{N}$-nitrosodiethylamine induced hepatocarcinogenesis. $J$ Appl Biomedicine 3: 187-191.

Milner JA 2001. Recent advances on the nutritional effects associated with the use of garlic as a supplement: a historical perspective on garlic and cancer. $J$ Nutr 131: 1027-1031.

Misra TN, Singh RS, Pandey HS, Sharma SC 1989. Aliphatic hydroxy-ketones from Adenocalymma alliaceum leaves. 
Phytochemistry 28: 933-936.

Misra TN, Singh RS, Pandey, HS 1991. Aliphatic compounds from Adenocalymma alliaceum leaves. Phytochemistry 30: 541-543.

Misra TN, Singh RS, Pandey HS, Prasad C, Sharma SC 1995. A novel pentacyclic triterpene acid from Adenocalymma alliaceum leaves. J Nat Prod 58: 1056-1058.

Pandey HS, Sharma SC, Singh RS, Misra TN 1992. Glycyrrhetol and $\beta$-peltoboykinolic acid from Adenocalymma alliaceum leaves. Planta Med 58: 225-225.

Pérez D 2002. Etnobotánica medicinal y biocidas para malaria en la región Ucayali. Folia Amazónica 13: 87-108.

Pimentel AAMP 1994. Cultivo de plantas medicinais na Amazônia. Belém: Faculdade de Ciências Agrárias do Pará.

Rana BK, Taneja V, Singh UP 1999. Antifungal activity of an aqueous extract of leaves of garlic creeper (Adenocalymma alliaceum Miers). Pharm Biol 37: 13-16.

Rao MA, Kjaer A, Madsen JO, Rao EV 1978. Diallyl di-, tri- and tetrasulphide from Adenocalymma alliacea. Phytochemistry 17: 1660-1661.

Rao MA, Rao VE 1980. Flavonoids of the flowers of Adenocalymma alliaceum. Curr Sci 49: 468-469.

Rao MA, Kjaer A, Olsen O, Rao EV, Rasmussen KW, Sorensen $\mathrm{H}$ 1981. Alliin in the garlicky taxon Adenocalymma alliaceum (Bignoniaceae). Phytochemistry 20: 822-823.

Rao MA, Rao EV 1982. Estimation of alliin in Adenocalymma alliacea and comparison with that of garlic. Indian Drugs 20: 6-7.

Rao EV, Rao MA 1982. Apigenin-7-O-methylglucuronide from Adenocalymma alliaceum. Curr Sci 51: 1040-1040.

Rao MA, Rao EV 1985. Antimicrobial activity of the leaf extract of Adenocalymma alliaceum. Indian Drugs 22: 364 365.

Rao LJM, Srinivas P, Gurudutt KN 1999. Chemical composition of the volatile oil from garlic creeper (Adenocalymma alliaceum). J Med Aromat Plant Sci 21: 987-989.

Revilla J 2001. Plantas da Amazônia. Oportunidades Econômicas e Sustentáveis. Manaus: Programa de Desenvolvimento Empresarial e Tecnológico.

Rocha AD, Oliveira AB de, Souza Filho JD de, Lombardi JA, Braga FC 2004. Antifungal constituents of Clytostoma ramentaceum and Mansoa hirsuta. Phytother Res 18: 463-467.

Sakamoto K, Lawson LD, Milner J 1997. Allyl sulfides from garlic suppress the in vitro proliferation of human A549 lung tumor cells. Nutr Cancer 29: 152-156.

Salman H, Bergman M, Bessler H, Punsky I, Djaddetti M 1999. Effect of garlic derivative (alliin) on peripheral blood cell immune response. Int J Immunopharmacol 21: 589-597.

Scogin R 1980. Anthocyanins of the Bignoniaceae. Biochem Syst Ecol 8: 273-276.

Sharma RK 1993. Phytosterols: wide-spectrum antibacterial agents. Bioorg Chem 21: 49-60.

Silva MF, Lisbôa PLB, Lisbôa RCL 1977. Nomes vulgares de plantas amazônicas. Belém: INPA.

Singh SV, Mohan RR, Agarwal R, Benson PJ, Hu X, Rudy MA, Xia H, Katoh A, Srivastava SK, Mukhtar H, Gupta V, Zaren HA 1996. Novel anti-carcinogenic activity of an organosulfide from garlic: inhibition of H-RAS oncogene transformed tumor growth in vivo by diallyl disulfide is associated with inhibition of $\mathrm{p} 21 \mathrm{H}$-ras processing. Biochem Biophys Res Commun 225: 660-665.
Srinivasan MR, Srinivasan K 1995. Hypocholesterolemic efficacy of garlic-smelling flower Adenocalymma alliaceum Miers. in experimental rats. Indian J Exp Biol 33: 64-66.

Sundaran SG, Milner JA 1995. Diallyl disulfide inhibits the proliferation of human tumor cells in culture. Biochim Biophys Acta 1315: 15-20.

Sundaran SG, Milner JA 1996a. Diallyl disulfide suppresses the growth of human colon tumor cell xerografts in athymic nude mice. J Nutr 126: 1355-1361.

Sundaran SG, Milner JA 1996b. Diallyl disulfide induces apoptosis of human colon tumor cells. Carcinogenesis 17: 669-673.

Thetburanatham V 1987. Dictionary of ornamental plants of Thailand. Bangkok: O. S. Printing House, p. 27-28.

Tsai SJ, Jenq SN, Lee H 1996. Naturally occurring diallyl disulfide inhibits the formation of carcinogenic heterocyclic aromatic amines in boiler pork juice. Mutagenesis 11: 235-240.

U.S. Environmental Protection Agency. Office of Pesticide Programs. Biopesticides and Pollution Division 2003. Diallyl sulfides. PC Code 129087.

Wagner H, Wierer M, Fessler B 1987. Effects of garlic constituents on arachidonate metabolism. Planta Med 53: 305-306.

Xiao D, Singh SV 2006. Diallyl trisulfide, a constituent of processed garlic, inactivates Akt to trigger mitochondrial translocation of BAD and caspase-mediated apoptosis in human prostatecancer cells. Carcinogenesis 27: 533540

Yeh YY, Liu L 2001. Cholesterol-lowering effect of garlic extracts and organosulfur compounds: human a+ and animal studies. J Nutr 131: 989-993.

Zoghbi MGB, Ramos LS, Maia JGS, Silva ML, Luz AIR 1984. Volatile sulfides of the Amazonian garlic bush. J Agric Food Chem 32: 1009-1010.

Zoghbi MGB, Andrade EHA, Maia JGS 2002. Volatile constituents from Adenocalymma alliaceum Miers and Petiveria alliacea L., two medicinal herbs of the Amazon. Flavour Frag J 17: 133-135. 